Niepełnosprawność. Dyskursy pedagogiki specjalnej

Marta Jurczyk

Uniwersytet Gdański

\title{
Ambiwalencja jako kategoria (dez)integracji pracy nauczyciela-terapeuty w Warsztacie Terapii Zajęciowej
}

\author{
Ambivalence as ( dis)integration category of educator - \\ therapist's activities at Occupational Therapy Workshop
}

The following considerations, the difficulty and the ambivalence of the roles undertaken teachertherapist in institutions which are Occupational Therapy Workshops are the result of their own empirical investigations related to the categories of special education and meanings broadcast specific aspects of this experience. In the article quoted statements are from interviews narrative with employees (teachers and therapists), Occupational Therapy Workshops. Ambivalent conditions of work of the teacher-therapist is an issue taken up in this article. The teacher here is involved in a number of educational and therapeutic processes and bureaucratic administration, which constitute the issue of accountability of work he does.

Słowa kluczowe: ambiwalencja, nauczyciel, dorosłość, niepełnosprawność, warsztat terapii zajęciowej

Keywords: ambivalence, teacher, adulthood, disability, occupational therapy workshop

\section{Wprowadzenie}

O niepełnosprawności intelektualnej w stopniu głębszym i głębokim, zwłaszcza w kontekście dorosłości i wyzwań, które naturalnie ze sobą niesie, nie dyskutuje się na co dzień. Problem ten może stanowić kwestię marginalizowaną lub pomijaną. Upośledzenie umysłowe w swoich dwóch ostatnich poziomach (głęboki i głębszy) jest obciażone największą stygmatyzacją (Zaorska 2005, s. 135), a sam aspekt upośledzenia determinuje „szanse i możliwości na rozwój indywidualny oraz pomyślną egzystencję w świecie społecznym, a co za tym idzie (buduje), społeczną izolację i wykluczenie" (tamże).

Problem stanowi swoisty rodzaj ambiwalencji $-\mathrm{z}$ jednej strony dostrzega się brak placówek dla osób dorosłych niepełnosprawnych, z drugiej natomiast zwra- 
ca się uwagę na wsparcie procesów usamodzielniających, pozwalających na autonomiczne funkcjonowanie w społeczeństwie - paradoksalnie oba aspekty służyć mogą za podstawę teoretycznych rozważań nad poszukiwaniem sensu dorosłości osób z głębszą i głęboką niepełnosprawnością intelektualną.

Niżej przedstawione rozważania nad trudnością i ambiwalencją podejmowanych ról nauczyciela-terapeuty w placówkach, jakimi są Warsztaty Terapii Zajęciowej, są wynikiem własnych dociekań empirycznych związanych z kategoriami „bycia-w-świecie” edukacji specjalnej i znaczeń nadawanych poszczególnym aspektom tego doświadczania. Zawarte $\mathrm{w}$ artykule cytowane wypowiedzi pochodzą z przeprowadzonych wywiadów narracyjnych z pracownikami (nauczycielami i terapeutami) Warsztatów Terapii Zajęciowej. Metodologicznie przyjmuję tutaj koncepcję F. Schutze, która to mówi, że „istotą wywiadu narracyjnego jest bowiem otrzymanie opowieści o życiu, niebędącej sumą odpowiedzi na stawiane pytania, lecz spontaniczną narracją, która nie jest zakłócona interwencją badacza. Celem wywiadu narracyjnego jest zatem uzyskanie od jednostki - nazywanej tutaj narratorem a nie respondentem - relacji o życiu lub wybranych jego fazach" (Kaźmierska 1996, s. 35). Wywiady te zostały przeprowadzone wśród 15 nauczycieli-terapeutów, różniących się stażem pracy i wiekiem - jednak różnicowania tych kategorii nie podejmuję w niniejszym artykule. Staż pracy tychże badanych to zarówno kilkuletnie doświadczenie etatowe, jak i wieloletnia (dokładnie 27 lat) praktyka w jednym ośrodku, różnice wiekowe to odpowiednio od 30 do 62 lat. Każdy z badanych posiada wykształcenie wyższe, kwalifikujące i uprawniające do podejmowanych działań edukacyjnych w opisywanych placówkach. Jednak zróżnicowanie grupy badawczej nie stanowi żadnej z kategorii analitycznych podejmowanych w niniejszym artykule zagadnień.

Kategorię ambiwalencji przyjmuję za L. Witkowskim (1994, s. 189), który opisuje ambiwalencję jako stan rozdarcia między emocjami czy pragnieniami (być twórczo-refleksyjnym dla ucznia czy biurokratycznym dla szkoły?), jako oscylacji między postawami wpisanymi w określone działania (na lekcji będę bardziej twórczy, na zebraniu z dyrektorem bardziej biurokratyczny) i nierozstrzygnięcia, które będzie tworzyć pozorne poczucie wyboru między którymkolwiek z aspektów, $\mathrm{w}$ efekcie nieskonkretyzowane na żadnym z nich. Ambiwalencja będzie konstruktem procesów społecznych, w których zachodzi pewien dysonans wartości. Ponadto kategoria ta będzie swoistym rodzajem doświadczania wpisanego $\mathrm{w}$ tworzenie procesów społecznych i ich transformacji. Tak precyzowane pojęcie ambiwalencji tworzy twierdzenie, że człowiek uwikłany jest w szereg różnych grup odniesienia, przyjmuje różnego rodzaju statusy i odgrywa nierzadko sprzeczne role. Nauczyciel-terapeuta będzie tutaj osobą, która w swojej pracy dotyka „wzajemnie ze sobą sprzecznych oczekiwań normatywnych" (tamże). Ambiwalentny charakter praktyk edukacyjno-terapeutycznych $\mathrm{w}$ podejmowanym arty- 
kule ogniskuję wokół opozycji racjonalności sformułowanych przez R. Kwaśnicę (2007) - racjonalności adaptacyjnej i emancypacyjnej.

\section{Warsztat terapii zajęciowej jako oferta edukacyjna}

Jedną z placówek, która stanowi swoistą ofertę dla aktywizacji zawodowospołecznej osób dorosłych z niepełnosprawnością, jest Warsztat Terapii Zajęciowej. Placówka ta nie jest miejscem opieki całodobowej, stanowi jedynie miejsce oferujące swoje 'usługi' w określonych godzinach. Usługi te stanowić powinny szereg form aktywizacji osób z niepełnosprawnością intelektualną, powinny pozwalać na rozwijanie zainteresowań a podstawowym celem pracy terapeuty w takiej placówce powinno być „,Zwiększanie zakresu samodzielności i zaradności życiowej podopiecznego, wdrażanie go do aktywności fizycznej i umysłowej, kształtowanie charakteru, rozwijanie osobowości (...) formy terapii powinny eliminować monotonię życia codziennego, nudę i pustkę" (Prysak 2008, s. 227).

Warsztat terapii zajęciowej jest taką placówką, do której ludzie są dowożeni od 7.00 do 15.00, a kto może z okolic dojeżdża sam. Było 25 osób, było 5 pracowni. Ja miałam pracownię ekologiczno-turystyczną. Moja działka to była ekologia, mieliśmy działkę, warzywa sialiśmy. Była kuchnia, która to wszystko przerabiała, plastyczna pracownia, stolarska i krawiecka.

Przedstawienie krótkiej informacji o funkcjonowaniu Warsztatu Terapii Zajęciowej nakreśla godziny jego dostępności dla podopiecznych i zakresie proponowanych form terapii zajęciowej, która zasadniczo nie odbiega w sposób znaczący od pozostałych placówek - różnice mogą jedynie wynikać z ograniczeń lokalowych czy też środowiskowych, jednak poszczególny elementy terapii zasadniczo pokrywają się. Formułowane przez J. Pańczyk (2004) terapie podstawowe to: biblioterapia, ergoterapia, kinezyterapia, logopedia, muzykoterapia, psychoterapia oraz rehabilitacja przez twórczość (arteterapia), w które to - w formie określonych kompetencji - powinien być wyposażony pedagog specjalny lub terapeuta pracujący w placówce. Rozporządzenie MNiSW z 17 stycznia 2012 r. w sprawie standardów kształcenia przygotowującego do wykonywania zawodu nauczyciela ${ }^{1}$ ( $w$ tym pedagoga specjalnego) stanowi, że pedagog specjalny poza wiedzą i umiejętnościami zawodowymi, w tym kompetencji z zakresu określonej specjalności zawodowej „(...) musi mieć również kompetencje niezwykłe” (Czajkowska 2008, s. 22), w które to właśnie wpisuje się wszystkie formy terapii podstawowych.

$\overline{1}$ http://isap.sejm.gov.pl/DetailsServlet?id=WDU20120000131 [dostęp: 14.12.2016]. 
Takie obwarowanie formalne dotyczące kompetencji osób pracujących z niepełnosprawnymi dorosłymi osobami pozwala na założenie, że osoby te najpełniej będą sprawowały opiekę i nadzór pedagogiczny nad procesami zachodzącymi w placówce, takiej jak np. Warsztat Terapii Zajęciowej.

\section{Racjonalność adaptacyjna}

Rzeczywistość jednak determinuje takie myślenie zarówno osób, które takowe placówki traktują jako jedną z form rewalidacji osób z niepełnosprawnością intelektualną, tych, którzy z 'usług' WTZ-tu korzystają (pośrednio: jako rodzina i bezpośrednio: jako osoba niepełnosprawna intelektualnie) oraz tych, którzy w takiej placówce pracują.

Przychodzili, Iksińskich trzeba było wykąpać, bo spali tam gdzie się położyli, z psami lub nie, gdzie się załatwili tam się kładli. Trzeba było ich wykąpać, dać czyste rzeczy... Potem rano np. kończyli jakąś pracę z poprzedniego dnia a ja jechałam z Maćkiem pomagać rehabilitantce ćwiczyć z Maćkiem, bo ze względu na porażenie czterokończynowe wykonywał dużo ćwiczeń. I wiesz - oni dojeżdżali. Potem dojeżdżali pozostali. Potem było śniadanie a po śniadaniu - co robimy? No to gdzie idziemy i ze względu na porę roku - taką czynność wykonywaliśmy. A to do ogródka, kopać czy siać. Łuskaliśmy słonecznik, potem coś robiliśmy z nasionami... I tak do 15.00. Wiesz... ja czasem nie robiłam tego co powinnam, $\mathrm{w}$ sensie, wiesz... że siedziałam z nimi i dłubałam słonecznik do 15.00. Zdarzało mi się na przykład wychodzić z nimi do miasta, pokazywałam im gdzie jest na przykład policja, przystanek i na przykład jak trafić na dworzec. Pewnie, dostałam po głowie, wiesz o co chodzi, że niby nie mam tak robić, bo oni mają siedzieć w WTZ-cie i robić to co mają a nie że wiesz ja im miasto pokazuję (...).

Placówka taka jak Warsztat Terapii Zajęciowej - jak każda inna instytucja zatrudniająca pracowników - nakreśla zakres obowiązków poszczególnych osób. I tu możemy wychwycić pewien rodzaj dysonansu, z jednej strony ",charakter pracy z osobami niepełnosprawnymi nasuwa konieczność poszukiwania takich metod i rozwiązań terapeutycznych, które najlepiej służą rewalidacji" (tamże, s. 23) - wobec czego działanie takie - jak powyżej - służące szeroko rozumianej orientacji w przestrzeni środowiska, usprawnianiu samodzielnego funkcjonowania społecznego nie jest praktyką pożądaną przez instytucję. Zakres obowiązków ogranicza się jedynie do budynku czy też terenu placówki. Mimo, iż „koniecznym staje się dwustronne podejście $w$ dążeniach i działaniach zmierzających do likwidacji społecznego upośledzenia osób niepełnosprawnych: 1) rehabilitacyjne skoncentrowane na rozwijaniu u osób niepełnosprawnych takiego zasobu dyspozycji i umiejętności, które pozwolą zniwelować ich trudności adaptacyjne w środowisku, 2) normalizacyjne - zmierzające do takiego unormowania (...) warun- 
ków egzystencji by niepełnosprawność przestała być powodem społecznego upośledzenia" (Maciarz 2005, s. 26). Takie właśnie działania, przedstawione trochę na zasadzie opozycyjności znaczeń czy też konkretniej mówiąc opierające się na konflikcie interesów obu stron, a tym samym powodujące pewien dysonans $\mathrm{w}$ orientacji działania pedagoga specjalnego, można sklasyfikować jako dwa rodzaje działań - w ramach racjonalności adaptacyjnej i racjonalności emancypacyjnej (Kwaśnica 2007). Racjonalność adaptacyjna będzie tutaj działaniem, które osobę niepełnosprawną intelektualnie traktować będzie jak przedmiot do naprawienia, który „należy poddać kontroli, opanować i podporządkować życiowo ważnym, ustanowionym (...) celom" (tamże, s. 85). Wszelkiego rodzaju praktyki pedagogiczne ograniczać się będą jedynie do czynności czysto technicznych, powtarzalnych, poznanych, zastanych i schematycznych, sprawdzonych w wyniku wcześniejszych założeń o skuteczności - czyli, jeśli coś dobrze funkcjonuje, nie warto tego zmieniać.

Wartości, które w działaniu zgodnie z tą racjonalnością będą zasadniczo wywodziły się z ich głębokiego zakorzenienia w świecie przedmiotowym, będą mierzalne, dające się ocenić $\mathrm{w}$ wymiernej skali. Zatem będą takimi wartościami, które w myśl tej właśnie racjonalności tworzyć będą teoretycznie zestaw dóbr, które stanowić będą o prawidłowym funkcjonowaniu człowieka jako istoty fizycznej i społecznej. Perspektywa adaptacyjna zakłada, że porządek tych wartości gwarantować będzie poczucie stabilności i bezpieczeństwa, ponadto wartości te są na tyle uniwersalne, że osiągnięcie sukcesu zależne jest tylko od osobistego wysiłku jednostki włożonego $\mathrm{w}$ proces ich zdobycia. Wartości te i ich zakorzenienie $\mathrm{w}$ świecie nastawione są na konsumpcję lub opcjonalnie na odtwarzanie zawartych w owym porządku dóbr. Świat zastany krystalizujący się w tej perspektywie to świat przedmiotów, nad którymi należy przejąć kontrolę, opanować i podporządkować tym celom, które ustanowione są jako ważne. Przyjmowane wartości determinują hierarchię interpretacji - rozgraniczają punkty widzenia, kryteria opisu rzeczywistości. Ponadto założenia interpretacyjne racjonalności adaptacyjnej zakładają zawieszenie wątpliwości dotyczących własnej wiedzy jako tych, które zagrażają naturalnemu porządkowi rzeczy i normalności, a także założenie, że inni ludzie postrzegają ową normalność i porządek rzeczy identycznie ze mną (Kwaśnica 2007).

\section{Racjonalność emancypacyjna}

Na początku to tak wiesz... rodzice zakładali, ze w tym WTZ-cie nauczą się czytać, pisać, liczyć i staną się „normalnymi ludźmi”, a ich niepełnosprawność no nie wiem... zniknie. A my często przez kilka lat walczyliśmy o to, żeby się ktoś X podpisał na liście 
obecności. Ale jak ten $X$ postawił to wydaje mi się, że... Że miał takie poczucie przynależności jakiejś do grupy, do nas (...).

Działania pedagogiczne w placówkach typu Warsztat Terapii Zajęciowej, zarówno te z obszaru edukacyjnego, jak i wychowawczego "podporządkowane są efektywności naprawczej, tj. usprawniania i korektury odchyleń od normy psychofizycznej lub kompensacji ich skutków" (Krause 2009, s. 95). Z jednej strony zrozumiały jest pewien rodzaj zadań rewalidacyjnych w procesach dydaktyczno-terapeutycznych $\mathrm{z}$ osobami niepełnosprawnymi intelektualnie, jednak aspekt instrumentalnego podejścia $\mathrm{w}$ działaniu $\mathrm{z}$ nimi jest dominujący. Takowe cechy mogą wykazywać również rodzice dorosłych osób z niepełnosprawnością intelektualną, zakładając, że po pobycie w placówce, nawet czasowym, pewne deficyty wpisane w określoną niepełnosprawność znikną, zatrą się lub zostaną „naprawione” chociażby poprzez naukę takich praktyk, które pozwolą na takie funkcjonowanie w środowisku lokalnym jakby danego deficytu nie było. Stanie się on niewidoczny, niezauważalny dla innych. Naturalna troska rodziców o akceptację ich dziecka w społeczeństwie zmienia się w potrzebę usprawniania nie tyle dla siebie, co dla innych, dla społeczeństwa. „Zakorzenione w mentalności społeczeństwa stereotypy(na ogół negatywne) postrzegania osoby niepełnosprawnej intelektualnie" (Zaorska 2005, s. 141), sprawiają, że osobę taką widzimy jako „agresywną, źle zachowującą się, a nawet groźną dla otoczenia” (tamże), a więc nadzieje, jakie pokładają rodzice w placówkach edukacyjno-terapeutycznych wiążą się z poczuciem akceptacji dla „inności” niepełnosprawnych, a tym samym z ich lepszym funkcjonowaniem w społeczeństwie i z nim.

Ja już kiedyś do mojego męża mówiłam, że..., że ja się tam nie denerwuję. A od osób, z którymi pracuję uczę się cierpliwości jakiejś takiej. Nie wiem z czego to może wynikać - może to głupie, ale może przez to, że ich szanuje, przez to, że ich niepełnosprawność jest o tyle widoczna, że każdego traktuje inaczej, do każdego indywidualnie podchodzę i wiem, że każdy z nich nie wiem... inaczej odczuwa nie wiem... reaguje? Szkoda, że wśród ludzi z normy intelektualnej nie ma takiej zasady, nie...?

Wiesz co? Chyba nie, bo dlatego, chyba jako jedyni my jako kadra, terapeuci, rehabilitanci występowaliśmy z nimi, jednakowo dzieliliśmy role, kwestie, zadania, wszystko. Jak np. pojechaliśmy na "Pozapozy” do Gdańska, zrobiliśmy „pociąg życia”, to wszyscy byli tak samo zaangażowani. Stolarnia coś zbijała, pracownia plastyczna coś tam malowała. Nie było nikogo kto nie czułby się niepotrzebny czy coś, bezużyteczny bez zajęcia. Nie było, ze patrzcie my to zrobimy (jako ich opiekunowie), żeby było ładnie. Nie - wszyscy jedziemy, wszyscy robimy, wszyscy występujemy. Zajęliśmy kiedyś nawet drugie miejsce w kategorii teatralnej. Słuchaj, my wałkujemy im poczucie własnej wartości, że nawet jak słyszą w domu tam od jakiejś ciotki czy coś bo to się zdarza, że oj jaki ty jesteś biedny, albo do rodziców, że wy to macie tak źle, bo takie i takie dziecko, wiesz (...). 
Nie pamiętam żeby przez 9 lat był ktoś kto by się obrazil, że ktoś się z niego śmiał. Pewnie, mieli tam jakieś swoje kłótnie, nie raz się ktoś zaczynał szarpać, ale nigdy jakoś nie obrażali się na siebie nawet po takim czymś, wiesz... My też np. uświadamialiśmy im, że oni nie są chorzy. Bo chory jesteś jak masz grypę. I oni nie czuli się gorzej, ale wiesz... „ale pani czemu oni mówią że jestem inny?”. I tu już było o tyle trudno, że jak można wytłumaczyć, że społeczeństwo takie jest? Ja im to tłumaczyłam trochę tak... może źle, nie wiem, ale bynajmniej się starałam tak, że Adam, ty nie możesz iść sam do banku, bo sobie nie poradzisz jak dojść i tak dalej, ja pójdę z Tobą. Ale jak np. będę chciała zrobić sobie półkę z ładnych deseczek to ja sobie tego nie zrobię, ale Ty mi już tak". Może to naiwne, ale starałam się w ogóle jakoś im to tłumaczyć... nie wiem... nie zostawiać bez odpowiedzi, że tak po prostu jest (...).

Zdarzało mi się na przykład wychodzić z nimi do miasta, pokazywałam im gdzie jest na przykład policja, przystanek i na przykład jak trafić na dworzec.

Indywidualne podejście i dostosowanie wymagań czy też praktyk wpisane jest opozycyjnie do racjonalności adaptacyjnej - w racjonalność emancypacyjną, w której to sam aspekt emancypacji pojmowanej jako „poszukiwanie możliwości wyzwalania się z wcześniej stworzonego i zaakceptowanego świata" (Kwaśnica 2007, s. 97) pozwala nam nakreślić obszar działalności pedagogicznej w pracy z niepełnosprawnymi intelektualnie, a przynajmniej wskazać kierunek takich praktyk. Ważne jest również podejście do drugiego człowieka w działaniu racjonalności emancypacyjnej. Odwrotnie niż w racjonalności adaptacyjnej, gdzie inni postrzegani się wyłącznie z punktu widzenia roli jaką mogą sprawować w społeczeństwie, a także korzyści lub zagrożeń, które niesie ze sobą ich obecność w procesach interpersonalnych - tutaj, inny jest partnerem do dialogu, jest osobą, która posiada określone doświadczenie, rozumie świat na swój indywidualny sposób i właśnie z tego punktu powinny wychodzić działania pedagogiczne, terapeutyczne czy też rewalidacyjne. Nie traktujemy tutaj osoby z niepełnosprawnością jako przedmiotu, z którym pracujemy, ale jako podmiot, który jest, który stanowi sam o sobie, którego sama obecność jest najważniejszym punktem odniesienia działań terapeutyczno-dydaktycznych.

Nauczyciel jako podejmujący refleksję nad własnym działaniem będzie tym, który emancypuje zarówno uczniów, kategorie wiedzy, jak i samego siebie. W ten sposób będzie poszukiwał innych możliwości widzenia świata, przedstawiania wartości, z których najważniejszą jest otwieranie się na inne znaczenia otaczającego nas świata, a przy tym formułowanie ich we własnym imieniu. Racjonalność emancypacyjna w kategorii systemu wartości „posiadać będzie inną od adaptacyjnej perspektywę aksjologiczną", która to determinowana jest wyjściem poza ramy odgórnie narzuconych wartości. Największą wartością w racjonalności emancypacyjnej będzie więc szeroko pojmowana zmiana. Dla twórczo-refleksyjnego aspektu działania nauczyciela może oznaczać to transformowanie włas- 
nych praktyk, wartości, które wykraczają poza jednostkową perspektywę nauczyciela i emancypowanie wiedzy z samych uczniów (poprzez odpowiednio sprecyzowane działania), tak by stali się jej twórcami a nie odbiorcami.

Założenia interpretacyjne racjonalności emancypacyjnej: o nieoczywistości świata, o uświadomieniu sobie, że "nie ma rzeczywistości obiektywnej w ogóle", a jego obiektywność tworzona jest indywidualnie przez jednostki, o obiektywności, którą każdy człowiek widzi subiektywnie, o braku posiadania pełnej mocy odczytania sensu działań i intencji innych i o posiadaniu przez każdego z nas specyficznego, charakterystycznego dla niego sposobu rozumienia okoliczności działania - te przesłanki automatycznie nakreślają założenia interpretacyjne działań pedagogicznych. W praktykach tych nie ma miejsca na wiedzę z góry właściwą czy niewłaściwą - każdą można poddać w wątpliwość.

Niektóre dorosłe osób z niepełnosprawnością intelektualną mają świadomość własnych ograniczeń, deficytów, własnego upośledzenia, odmienności względem innych „z normą". Jednak gorzej jest z wiedzą o otaczającym je świecie, o prawach im przysługującym, o organizacjach mających na celu ich wspieranie. Istotne zatem, w procesach edukacyjno-terapeutycznych staje się przekazywanie wiedzy o świecie, w którym żyją, a tym samym o utrudnieniach czy też rozwiązaniach związanych bezpośrednio z ich funkcjonowaniem jako osób niepełnosprawnych, bo już "samo dostrzeganie możliwości aktywnego działania zwiększa poczucie kontroli nad własnym życiem, zapobiega paraliżującej niemożności i bezsilności" (Ostrowska 2007, s. 53).

Wyjście naprzeciw potrzebom dorosłych osób z niepełnosprawnością nie powinno ograniczać się do podawania gotowych rozwiązań, kierowania do określonych placówek edukacyjno-terapeutycznych, ale na takim przygotowaniu środowiska czy też jego elementów, by było ono gotowe na przyjęcie takich osób do pracy, do wspólnoty, do stanowienia jednej ze składowej części danej społeczności. Na ogół to „inni wyznaczają jakość życia osoby niepełnosprawnej intelektualnie, często w sposób nieadekwatny do jej potrzeb i bez jej zgody" (Żółkowska 2007 , s. 241). Takie decydowanie zasadniczo opiera się na przeświadczeniu, jakoby osoby z niepełnosprawnością intelektualną nie posiadały odpowiednich kompetencji do podejmowania ważnych, życiowych decyzji, że nie są do nich zdolni. A przecież to właśnie stanowi podstawowy sens dorosłości - odpowiedzialność za podejmowane samodzielnie decyzje, świadomość ich konsekwencji i wybór ich zgodnie z własnymi przekonaniami, przeświadczeniami czy preferencjami.

Tam było mi spokojniej, bo starałam się wypracować jakieś takie poczucie zaufania, czy tam odpowiedzialności czyli, że jak idziemy gdzieś to razem, nie uciekamy sobie nawzajem. Ja się czułam za te osoby odpowiedzialna, mówiłam im to i też mówiłam, że skoro są dorośli to powinni się tak zachowywać - że wiesz, że skoro ja jestem za nie odpowiedzialna, to oni nie powinni mnie zawieść. 
Były chwile zwątpienia, ja mówię... wiesz... to pewnie przychodzi z czasem, niekiedy rodzice taki Ci podcinali skrzydła, że ręce opadały, bo rodzice mieli inne wizje, roszczeniowe postawy, wiesz. Ale ja ogólnie uważam, że to była dobra praca. Pewnie, że może mało opłacalna, ale ja chciałam to robić. Nie miałam wiesz poczucia, że jestem jak misjonarka czy coś, że oto ja robię coś nie wiem dobrego czy coś. Nie. Ale byłam dla tych osób, one widziały, że nie jestem z rodziny a mimo tego nie wykrzywiam twarzy na ich widok... Jeśli im było chociaż trochę lepiej, bo np. nie wiem... mogłam dawać nadzieję, że na zewnątrz warsztatu też są tacy ludzie (...).

\section{Zakończenie}

Specyfika pracy z niepełnosprawnym dorosłym nakreśla znacząco inne perspektywy niż praca z niepełnosprawnym dzieckiem. W obu przypadkach wszelkiego rodzaju działania pedagogiczno-wychowawcze oscylować będą wokół kategorii usprawniania, rewalidacji i rehabilitacji. Ciekawą kwestią, która mogłaby stanowić jeden z elementów zmiany społecznej dla osób z niepełnosprawnością intelektualną, jest transformacja dotychczasowego systemu kształcenia pedagogów specjalnych. „Najczęstszym czynnikiem wyznaczającym charakter wielospecjalistycznych instytucji jest wiek osób, dla których zostały one utworzone a nie rodzaj niepełnosprawności" (Parys 2007, s. 304) - wobec czego adekwatne powinno być zróżnicowanie specjalizacyjne kształcenia pedagogów ze względu na specyfikę pracy zgodną z wiekiem grupy docelowej. Kwestia rehabilitacji i rewalidacji dorosłych osób z niepełnosprawnością powinna stanowić przedmiot osobnej specjalizacji - przede wszystkim ze względu na złożoność i specyfikę zjawiska, wieloznaczność pracy pedagoga czy też terapeuty a także ze względu na niszowość problemu głębszej i głębokiej niepełnosprawności intelektualnej. Stanowić to może niejednokrotnie kategorię rozstrzygalnie trudną właśnie z racji faktu ambiwalentnych uwarunkowań pracy nauczyciela-terapeuty, który to uwikłany jest w szereg procesów edukacyjno-terapeutycznych, jak i biurokratyczno-administracyjnych, które wyrokują kwestię rozliczalności wykonywanej pracy.

\section{Bibiliografia}

Czajkowska M. )2008), Przygotowanie zawodowe pedagogów specjalnych do uczestnictwa w procesie edukacji i rehabilitacji [w:] Kompetencje pedagoga specjalnego. Aktualne wyzwania teorii i praktyki, red. Z. Palak, A. Bujanowska, Wydawnictwo UMCS, Lublin.

Kaźmierska K. (1996), Wywiad narracyjny - technika i pojęcia analityczne [w:] Biografia a tożsamość narodowa, red. M. Czyżewski, A. Piotrowski, A. Rokuszewska-Pawełek, Uniwersytet Łódzki, Łódź. 
Krause A. (2009), Iluzja dydaktycznej sprawczości- profesjonalizacja niekompetencji [w:] Paradygmaty wspótczesnej dydaktyki, red. L. Hurło, D. Klus-Stańska, M, Łojko, Oficyna Wydawnicza „Impuls”, Kraków.

Kwaśnica R. (2007), Dwie racjonalności: od filozofii sensu ku pedagogice ogólnej, Wydawnictwo Naukowe DSWE, Wrocław.

Maciarz A. (2005), Normalizacja szansa likwidacji społecznego upośledzenia osób niepetnosprawnych [w:] Sfery życia osób z niepetnosprawnościa intelektualną, red. Z. Janiszewska-Nieścioruk, Oficyna Wydawnicza „Impuls”, Kraków.

Ostrowska A. (2007), Kompetencje społeczne osób niepełnosprawnych-bariery dorosłości [w:] Dorostość, niepetnosprawność, czas wspótczesny. Na pograniczach pedagogiki specjalnej, red. K.D. Rzedzicka, A. Kobylańska, Oficyna Wydawnicza „Impuls”, Kraków.

Pańczyk J. (2004), Rola kompetencji (dyspozycji instrumentalnych i osobowościowych)pedagogów specjalnych we wsparciu osób rehabilitowanych i resocjalizowanych [w:] Wsparcie społeczne w rehabilitacji i resocjalizacji, red. Z. Palak, Z. Bartkowicz, Wydawnictwo UMCS, Lublin.

Parys K. (2007), Kształcenie pedagogów specjalnych a rzeczywiste potrzeby systemu edukacji i rehabilitacji osób niepetnosprawnych [w:] Osoba z niepetnosprawnością w systemie rehabilitacji, red. Cz. Kosakowski, A. Krause, A. Żyta, Wydawnictwo UWM.

Prysak D. (2008), Sylwetka terapeuty w domu pomocy społecznej [w:] Kompetencje pedagoga specjalnego. Aktualne wyzwania teorii i praktyki, red. Z. Palak, A. Bujanowska, Wydawnictwo UMCS, Lublin.

Witkowski L. (1994), Ambiwalencja jako kategoria dla socjologii edukacji [w:] Edukacja wobec zmiany społecznej, red. J. Brzeziński, L. Witkowski, Wydawnictwo Edytor, Torun.

Zaorska M. (2005), "Szanse i ograniczenia w systemie edukacji i rehabilitacji osób z niepetnosprawnościq intelektualna [w:] Sfery życia osób z niepetnosprawnościq intelektualną, red. Z. Janiszewska-Nieścioruk, Oficyna Wydawnicza „Impuls”, Kraków.

Żółkowska T. (2007), Wartościowanie pojęcia "dorosłość” przez osoby niepetnosprawne intelektualnie [w:] Dorostość, niepetnosprawność, czas wspótczesny. Na pograniczach pedagogiki specjalnej, red. K.D. Rzedzicka, A. Kobylańska, Oficyna Wydawnicza „Impuls”, Kraków. 